\title{
TERAMPIL
}

Jurnal Pendidikan dan Pembelajaran Dasar

\section{LKPD BERBASIS SCIENTIFIC APPROACH TERHADAP KEMAMPUAN PEMECAHAN MASALAH PESERTA DIDIK SEKOLAH DASAR KOMARUDIN}

Email: qhomar8@gmail.com

PRISMA TEJA PERMANA

Email: skurniasih0@gmail.com

STKIP AL Islam Tunas Bangsa Bandar Lampung Indonesia

Volume 6 Nomor 1, Juni 2019

\section{Abstract}

This study aimed to construct LKPD using scientific approach-based which was valid, practical, and interesting. The focus of this research was LKPD development based on the expansion of research procedure through four stages: self-evaluation, expert review and one-to-one, and small group. The data analysis was conducted in two steps: (1) descriptive, the data were obtained from documentation techniques such as the students' answer and response, and (2) students' answers were descriptively analyzed. The results of this development revealed that (1) The material expert's judgment reached a high interpretation criterion with the average percentage of 70\%, the assessment of the media expert reached the highest interpretation criterion with the average percentage $80 \%$, and validation by the practitioner reached higher interpretation criterion than material expert's judgment with percentage 79\% average; (2) Response of elementary students toward LKPD based on scientific approach on small group test consisting of 10 students and large group test involving 32 students indicated very high criteria. These findings showed that LKPD development contributed toward students' interest and can be used as one of supporting media in learning.

Keywords: Development Of LKPD; Scientific Approach, Problem Solving

Abstrak

Penelitian ini bertujuan untuk mengembangkan Lembar Kerja Peserta Didik (LKPD) menggunakan pendekatan ilmiah yang valid, praktis, dan menarik. Fokus penelitian ini adalah pengembangan LKPD berdasarkan pada perluasan prosedur penelitian melalui empat tahap: evaluasi diri, tinjauan ahli dan satu-ke-satu, dan kelompok kecil. Analisis data dilakukan dalam dua langkah: (1) deskriptif, data diperoleh dari teknik dokumentasi seperti jawaban dan respons siswa, dan (2) jawaban siswa dianalisis secara deskriptif. Hasil pengembangan ini mengungkapkan bahwa (1) Penilaian ahli materi mencapai kriteria interpretasi tinggi dengan persentase rata-rata $70 \%$, penilaian pakar media mencapai kriteria interpretasi tertinggi dengan persentase rata-rata $80 \%$, dan validasi oleh praktisi. mencapai kriteria interpretasi yang lebih tinggi daripada penilaian ahli materi dengan persentase rata-rata 79\%; (2) Respon siswa sekolah dasar terhadap LKPD berdasarkan pendekatan ilmiah pada tes kelompok kecil yang terdiri dari 10 siswa dan tes kelompok besar yang melibatkan 32 siswa menunjukkan kriteria yang sangat tinggi. 
Temuan ini menunjukkan bahwa pengembangan LKPD berkontribusi terhadap minat siswa dan dapat digunakan sebagai salah satu media pendukung dalam pembelajaran.

Kata kunci: Pengembangan LKPD; Pendekatan Ilmiah, Pemecahan Masalah

\section{A. PENDAHULUAN}

Perubahan kurikulum sebelumnya menjadi kurikulum 2013 dipandang sebagai langkah maju untuk memperbaiki mutu pendidikan. Secara teoritis dan penerapan dilapangan, maka nuansa tematik dan ilmiah (scientific) yang diusung oleh kurikulum 2013 sangat erat dengan pembelajaran matematika. Esensi pendekatan ilmiah (scientific approach) dalam pembelajaran merujuk pada pandangan bahwa pembelajaran pada dasarnya merupakan proses ilmiah yang harus dilakukan oleh peserta didik dan guru sebagai upaya dalam mengonstruksi dan mengajarkan bagaimana ilmu pengetahuan diperoleh dan dikembangkan. Sehingga pendekatan ini diharapkan dapat mengembangkan kemampuan berpikir ilmiah, logis, kritis, kreatif, dan objektif peserta didik agar sesuai dengan fakta yang ada. Selain itu, scientific approach dipandang paling cocok dalam pengembangan sikap, keterampilan, dan pengetahuan peserta didik. Mengacu pada hal tersebut, matematika hendaknya diarahkan untuk mengembangkan kemampuan berpikir ilmiah dan penyelesaian masalah peserta didik. Kemampuan pemecahan masalah adalah tujuan umum dari pembelajaran matematika dan merupakan kemampuan dasar yang harus dikembangkan dalam pembelajaran matematika. Maka sudah saatnya komposisi pemecahan masalah matematika mendominasi LKPD pada setiap materi khususnya peserta didik SD dimana secara psikologis kegiatan berpikir sudah mulai dikembangkan. Permasalahan tersebut mengisyaratkan bahwa belajar matematika akan lebih bermakna ketika belajar mengarah pada nuansa scientific. Oleh karena itu, dipandang perlu untuk mengembangkan LKPD matematika yang scientific approach sebagai langkah untuk mewujudkan pembelajaran matematika yang sesungguhnya.

Berdasarkan beberapa penelitian yang telah dilakukan sebelumnya, pengembangan lembar kerja siswa telah banyak dilakukan dalam berbagai penelitian (Febriana, Sulur, \& Yudyanto, 2014; Fitriana, Yusuf, \& Susanti, 2016; Pratama \& Prastyaningrum, 2016; Purwanto, 2014; Supardi, Rakhmawati, \& Rinaldi, 2018; Susialita, 2016; Utami, Hastuti, Yatimah, Padmini, \& Arroyan, 2013) begitupun dengan penggunaan pendekatan Scientific Approach (Fitriana et al., 2016; Yuliati, Riantoni, \& Mufti, 2018) serta penelitian dalam meningkatkan kemampuan pemecahan masalah (Agoestanto, Arief, \& Safitri, 2013; Alba, Khotim, \& Junaedi, 2013; E, S, \& Mashuri, 2015; Imamah \& Toheri, 2014; Kurniasari, Dwijanto, \& Soedjoko, 2014; Lipianto et al., 2013; Minarni, 2012; Syazali, 2015). Namun, belum adanya penelitian yang mengembangkan LKPD 
berbasis Scientific Approach guna meningkatkan kemampuan pemecahan masalah.

Keterbaruan penelitian ini terletak pada pengembangan LKPD berbasis Scientific Approach guna meningkatkan kemampuan pemecahan masalah peserta didik sekolah dasar. Maka, tujuan penelitian ini adalah untuk mengembangkan LKPD berbasis Scientific Approach yang valid, praktis, dan menarik

\section{B. METODE PENELITIAN}

Jenis penelitian yang digunakan adalah penelitian pengembangan menggunakan model Borg and Gall(Sugiyono, 2011) yang terdiri atas empat langkah yaitu: 1) Self Evaluation; 2) Expert Review dan One-to-one evaluation; 3) SmallGroup 4) Field Test.

Pengumpulan data dilakukan dengan teknik angket (kuesioner). Adapun analisis data dilakukan dengan analisis deskriptif yaitu menceritakan data hasil validasi ahli dan respon peserta didik terhadap LKPD matematika berbasis scientific approach. Adapun kriteria interpretasi yang digunakan berdasarkan Tabel 1 berikut ini.

Tabel 1

Kriteria Interpretasi

\begin{tabular}{cc}
\hline Hasil Tes & Kriteria \\
$86-100$ & SangatBaik \\
$71-85$ & Baik \\
$56-70$ & Sedang \\
$41-55$ & Rendah \\
$0<40$ & Sangat Rendah \\
\hline \multicolumn{2}{c}{ (Modifikasi Djaali, 2004:139) }
\end{tabular}

\section{HASIL PENELITIAN DAN PEMBAHASAN \\ 1. Hasil Penelitian}

Penelitian ini menghasilkan LKPD Matematika berbasis Scientific Approach pada materi pecahan peserta didik kelas V SD yang valid pada penilaian ahli dan menarik pada respon peserta didik. Adapun hasil pengembangan LKPD yang telah dilakukan adalah sebagai berikut:

Pada langkah Self Evaluation, diketahui bahwapembelajaran peserta didik kelas $\mathrm{V}$ belum menggunakan LKPD, dalam proses pembelajaran guru hanya menggunakan buku paket. Sehingga bahan ajar yang digunakan belum dapat menunjang kebutuhan bahan ajar yang seharusnya untuk proses pembelajaran. Selain itu, belum ada LKPD yang dikembangkan dan dirancang secara khusus menggunakan Scientific Approach. Pada langkah pengembangan ini juga peneliti telah melakukan pengumpulan informasi untuk mengetahui kebutuhan peserta didik terhadap bahan ajar yang dikembangkan melalui penelitian dan pengembangan. Langkah pertama peneliti melakukan analisis perkembangan peserta didik SD, berdasarkan perkembangan peserta didik SD yaitu peserta didik sangat tertarik belajar secara berkelompok di banding belajar secara mandiri. Setelah melakukan analisis perkembangan peserta didik, peneliti melakukan analisis materi, dalam pengembangan bahan ajar ini, yaitu materi pecahan.

Karakteristik yang ada pada materi pecahan memungkinkan peserta didik untuk belajar secara berkelompok, yaitu pada saat menyelidiki sifat-sifat operasi perkalian pecahan dan penerapannya dalam kehidupan 
sehari-hari. Análisis RPP yang digunakan guru di sekolah tersebut sudah sering menggunakan metode kooperatif, namun metode kooperatif yang digunakan merupakan diskusi biasa, yang belum membentuk kelompok belajar secara heterogen dan guru belum menggunakan LKPD, khususnya LKPD matematika berbasis scientific approach.

Setelah proses analisis dan pengumpulan informasi dilakukan, selanjutnya peneliti mulai mendesain LKPD sesuai analisis kebutuhan dan informasi yang didapatkan. Ada beberapa hal yang dilakukan diantaranya adalah menyesuaikan materi dengan kompetensi inti dan kompetensi dasar serta silabus yang ingin dicapai berdasarkan kurikulum 2013. Desain LKPD matematika berbasis Scientific Approach pada materi pecahan menggunakan ukuran kertas A5; skala space 1,5; font $12 \mathrm{pt}$; jenis huruf Cambria.Adapun susunan desain LKPD terdiri dari cover depan dan cover belakang, kata pengantar, halaman tim pengembang LKPD, peta konsep, petunjuk penggunaan LKPD dan daftar isi. Selain itu, LKPD yang dikembangkan terdiri dari Standar Isi (SI), tujuan pembelajaran, petunjuk umum LKPD, kegiatan Scientific Approach meliputimengamati, menanya dan mengkomunikasikan, mengumpulkan informasi, dan mengasosiasi, disamping itu juga terdapat kegiatan uji pemahaman, refleksi dan daftar pustaka.

Pada langkah Expert Review dan One-to-one evaluation, LKPD matematika berbasis ScientificApproach diuji oleh 6 pakar (ahli), yang terdiri dari 2 ahli materi, 2 ahli media, dan 1 ahli bahasa. Kriteria dalam penentuan subyek ahli, yaitu: (1) berpengalaman dibidangnya; (2) berpendidikan minimal S2. Validasi juga dilakukan oleh 1 praktisi yaitu guru SD, dengan kriteria sebagai subyek praktisi adalah: (1) berpengalaman dibidangnya; (2) berpendidikan minimal S1; (3) merupakan guru matematika di SD. Instrumen validasi menggunakan skala Likert. Adapun hasil validasi ahli dan validasi praktisi adalah sebagai berikut:

\section{a. Ahli materi}

Pada validasi ahli materi persentase validasi peraspek diperoleh dari jumlah jawaban responden peraspek dibagi jumlah nilai ideal peraspek dikali dengan $100 \%$, untuk memperoleh persentase rataan diperoleh dari jumlah persentase total semua aspek dibagi dengan banyaknya aspek. Setelah memperoleh hasilnya, sehingga diperoleh kriteria interpretasi yang telah ditentukan. Penilaian dari validator ahli materi disajikan dalam Tabel 2 berikut ini :

Tabel 2

Rekapitulasi Hasil Validasi Ahli Materi

\begin{tabular}{lcccc}
\hline \multicolumn{1}{c}{ Aspek } & $\begin{array}{c}\text { Jumlah skor } \\
\text { gabungan } \\
\text { peraspek }\end{array}$ & $\begin{array}{c}\text { Skor } \\
\text { Ideal } \\
\text { peraspek }\end{array}$ & $\begin{array}{c}\text { Persentase } \\
\text { Validasi } \\
\text { peraspek }\end{array}$ & $\begin{array}{c}\text { Kriteria } \\
\text { Interpretasi }\end{array}$ \\
Kualitas Isi & 22 & 30 & $73 \%$ & Baik \\
Cakupan Materi & 25 & 30 & $83 \%$ & Baik \\
Kooperatif & 11 & 15 & $73 \%$ & Baik \\
Motivasi & 10 & 15 & $67 \%$ & Sedang \\
Bahasa & 22 & 30 & $73 \%$ & Baik
\end{tabular}




\begin{tabular}{lcccc}
\hline \multicolumn{1}{c}{ Aspek } & $\begin{array}{c}\text { Jumlah skor } \\
\text { gabungan } \\
\text { peraspek }\end{array}$ & $\begin{array}{c}\text { Skor } \\
\text { Ideal } \\
\text { peraspek }\end{array}$ & $\begin{array}{c}\text { Persentase } \\
\text { Validasi } \\
\text { peraspek }\end{array}$ & $\begin{array}{c}\text { Kriteria } \\
\text { Interpretasi }\end{array}$ \\
Ilustrasi & 40 & 60 & $67 \%$ & Sedang \\
Evaluasi Penilaian & 11 & 15 & $73 \%$ & Baik \\
Jumlah total & 141 & 195 & & \\
Persentase rerata & & & $72 \%$ & \\
Kriteria Interpretasi & & & Baik & \\
\hline
\end{tabular}

Berdasarkan hasil validasi ahli materi, penilaian terhadap LKPD yang dikembangkan mencapai kriteria interpretasi Baik. Jumlah persentase validasi pada aspek kualitas isi adalah $73 \%$ dengan kriteria interpretasi Baik, pada aspek cakupan materi mencapai persentase $83 \%$ dengan kriteria interpretasi baik, persentase $73 \%$ dicapai pada aspek kooperatif, bahasa dan evaluasi dengan kriteria interpretasi Baik dan persentase $67 \%$ dicapai pada aspek motivasi dan ilustrasi dengan kriteria interpretasi cukup. Hasil validasi ahli materi keseluruhan aspek yang berasal dari penilain 3 ahli materi berjumlah total 141-skor ideal (maksimum) 195-dengan persentase $72 \%$ sehingga mendapat kriteria interpretasi baik. Diagram hasil validasi ahli materi dapat dilihat pada Gambar 1 berikut ini:

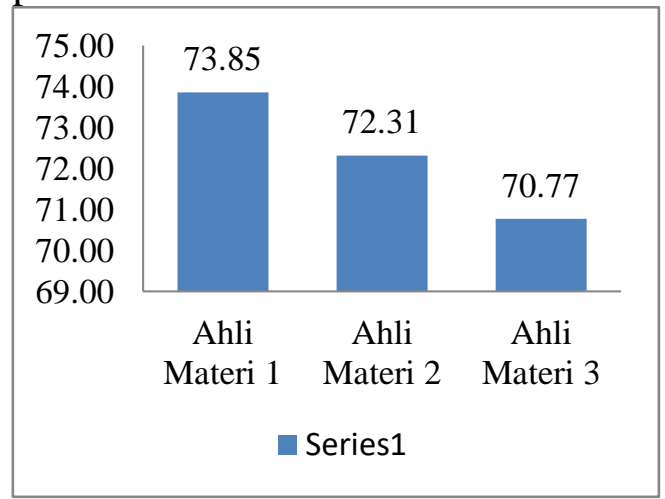

Gambar 1. Grafik Hasil Validasi Ahli Materi
Berdasarkan Gambar 1 hasil validasi ahli materi di atas, ahli materi pertama menilai LKPD dengan jumlah persentase $73,83 \%$ dengan kriteria interpretasi Baik, pada ahli materi kedua menilai LKPD dengan jumlah persentase $72,31 \%$ dengan kriteria interpretasi baik, serta ahli materi yang ketiga menilai LKPD dengan jumlah persentase $70,77 \%$ dengan kriteria interpretasi Baik. Secara keseluruhan hasil dari penilaian ahli materi tersebut dapat disimpulkan bahwa LKPD yang dikembangkan oleh peneliti berada pada kualifikasi yang Baik, yang artinya LKPD berbasis Scientific Approach pada materi pecahan perlu revisi kecil dan tidak perlu dilakukan validasi kembali.

\section{a. Validasi ahli media}

Hasil rekapitulasi validasi oleh ahli media terhadap pengembangan LKPD berbasis Scientific Approach pada materi pecahan dapat disajikan dalam Tabel 3 berikut ini: 
Tabel 3

Rekapitulasi Hasil Validasi Ahli Media

\begin{tabular}{lcccc}
\hline \multicolumn{1}{c}{ Aspek } & $\begin{array}{c}\text { Jumlah } \\
\text { skor } \\
\text { peraspek }\end{array}$ & $\begin{array}{c}\text { Skor Ideal } \\
\text { peraspek }\end{array}$ & $\begin{array}{c}\text { Persentase } \\
\text { Validasi } \\
\text { peraspek }\end{array}$ & $\begin{array}{c}\text { Kriteria } \\
\text { Interpretasi }\end{array}$ \\
\hline Format & 36 & 45 & $80 \%$ & Baik \\
Organisasi & 35 & 45 & $78 \%$ & Baik \\
Daya Tarik & 37 & 45 & $82 \%$ & Baik \\
Ukuran Huruf & 51 & 60 & $85 \%$ & Baik \\
Bahasa & 35 & 45 & $78 \%$ & Baik \\
Konsistensi & 45 & 60 & $75 \%$ & Baik \\
\hline Jumlah total & 239 & 300 & & \\
\hline persentase rataan & & & $79 \%$ & \\
\hline Kriteria Interpretasi & & & Baik \\
\hline
\end{tabular}

Hasil validasi ahli media persentase validasi peraspek diperoleh dari jumlah jawaban responden peraspek dibagi jumlah nilai ideal peraspek dikali dengan 100, untuk memperoleh persentase rataan diperoleh dari jumlah persentase total semua aspek dibagi dengan banyaknya aspek. Setelah memperoleh hasilnya, sehingga diperoleh kriteria interpretasi yang telah ditentukan.

Berdasarkan hasil validasi ahli media, penilaian terhadap LKPD yang dikembangkan mencapai kriteria interpretasi Baik. Jumlah persentase validasi pada aspek format penyusunan adalah $80 \%$ dengan kriteria interpretasi Baik, pada aspek organisasi penyusunan mencapai persentase $78 \%$ dengan kriteria interpretasi baik, pada aspek daya tarik LKPD mencapai persentase $82 \%$ dengan kriteria interpretasi baik, pada aspek penggunaan ukuran huruf mencapai persentase $85 \%$ dengan kriteria interpretasi baik, pada aspek bahasa yang digunakan mencapai persentase $78 \%$ dengan kriteria interpretasi baik, dan pada aspek konsistensi LKPD mencapai persentase $75 \%$ dengan kriteria interpretasi baik.
Hasil validasi ahli media dari keseluruhan aspek yang berasal dari penilain 3 ahli media berjumlah total 239-skor ideal (maksimum) 300dengan persentase $79,67 \%$ sehingga mendapat kriteria interpretasi baik. Adapun hasil rekapitulasi ahli media untuk masing-masing ahli media disajikan dalam Gambar 2 berikut ini:

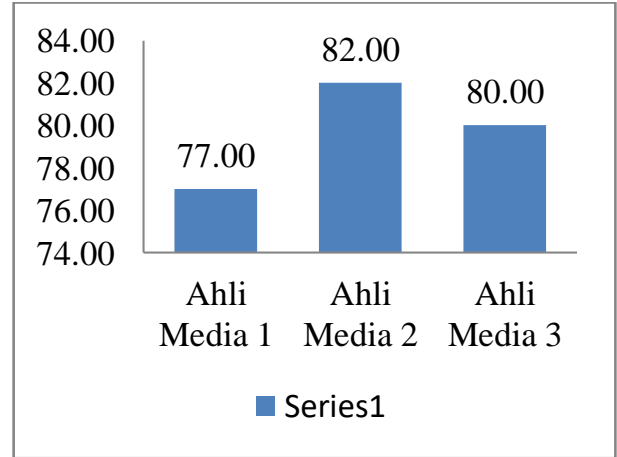

Gambar 2. Grafik Hasil Validasi Ahli Media

Berdasarkan Grafik hasil validasi ahli media di atas, bahwa validator ahli media pertama menilai LKPD dengan jumlah persentase $77 \%$ sehingga kriteria interpretasi yang di capai yaitu baik, penilaian kedua mencapai jumlah persentase yaitu $82 \%$ yaitu kriteria interpretasi baik dan penilaian ketiga mencapai jumlah persentase yaitu $80 \%$ yaitu 
kriteria interpretasi baik. Secara keseluruhan dapat disumpulkan bahwa penilaian ahli media terhadap LKPD sudah baik, tetapi perlu adanya perbaikan LKPD sesuai saran yang disampaikan oleh masingmasing ahli media.

\section{b. Validasi praktisi}

Pada validasi praktisi, persentase validasi peraspek diperoleh dari jumlah jawaban responden peraspek dibagi jumlah nilai ideal peraspek dikali dengan 100\%, untuk memperoleh persentase rataan diperoleh dari jumlah persentase total semua aspek dibagi dengan banyaknya aspek. Setelah memperoleh hasilnya, maka diperoleh kriteria interpretasi yang telah ditentukan.

Rekapitulasi hasil validasi oleh guru matematika terhadap LKPD berbasis Scientific Approach pada materi pecahan dapat dilihat pada Tabel 4 berikut ini

Tabel 4.

Rekapitulasi Hasil Validasi Ahli Praktisi

\begin{tabular}{lcccc}
\hline \multicolumn{1}{c}{ Aspek } & $\begin{array}{c}\text { Jumlah } \\
\text { Skor } \\
\text { peraspek }\end{array}$ & $\begin{array}{c}\text { Skor Ideal } \\
\text { peraspek }\end{array}$ & $\begin{array}{c}\text { Persentase } \\
\text { Validasi } \\
\text { peraspek }\end{array}$ & $\begin{array}{c}\text { Kriteria } \\
\text { Interpretasi }\end{array}$ \\
Kualitas Isi & 15 & 20 & $75 \%$ & Baik \\
Cakupan Materi & 16 & 20 & $80 \%$ & Baik \\
Kooperatif & 8 & 10 & $80 \%$ & Baik \\
Motivasi & 8 & 10 & $80 \%$ & Baik \\
Bahasa & 17 & 20 & $85 \%$ & Baik \\
Ilustrasi & 25 & 40 & $63 \%$ & Cukup \\
Evaluasi Penilaian & 8 & 10 & $80 \%$ & Baik \\
Jumlah total & 97 & 130 & & \\
Persentase rerata & & & $74,62 \%$ & \\
Kriteria Interpretasi & & & & \\
\hline
\end{tabular}

Berdasarkan hasil validasi ahli materi, penilaian terhadap LKPD yang dikembangkan mencapai kriteria interpretasi Baik. Jumlah persentase validasi pada aspek kualitas isi adalah 75\% dengan kriteria interpretasi Baik, persentase $80 \%$ dicapai pada aspek cakupan materi, motivasi, dan evaluasi, dan sedangkan persentase validasi pada aspek bahasa adalah 85\% dengan kriteria interpretasi Baik, dan pada aspek ilustrasi mencapai persentase $63 \%$ dengan kriteria interpretasi cukup.

Hasil validasi ahli materi keseluruhan aspek yang berasal dari penilain 3 ahli materi berjumlah total $97-$ skor ideal (maksimum) 130-dengan persentase $\quad 74,62 \% \quad$ sehingga mendapat kriteria interpretasi baik. Diagram hasil validasi ahli praktisi dapat dilihat pada Grafik 4.1 berikut ini:

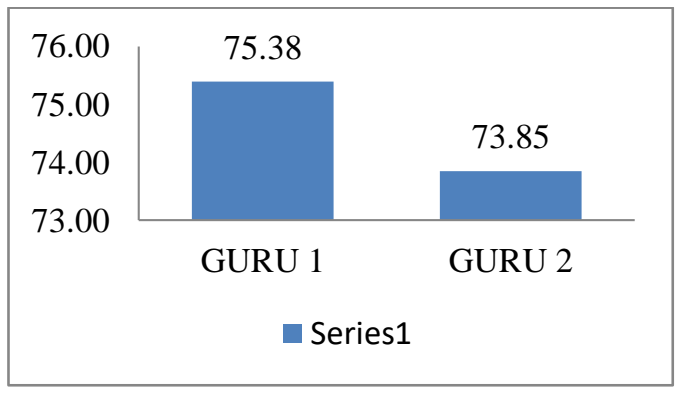

Gambar 3. Grafik Hasil Validasi Ahli Praktisi

Berdasarkan Gambar 3 hasil validasi ahli praktisi di atas, ahli praktisi 
KOMARUDIN \&

PRISMA TEJA PERMANA

pertama dan kedua sama-sama menilai LKPD dengan jumlah persentase $75,38 \%$ dan 73,85 dengan kriteria interpretasi Baik. Secara keseluruhan hasil dari penilaian ahli materi tersebut dapat disimpulkan bahwa LKPD yang dikembangkan oleh peneliti berada pada kualifikasi

yang Baik, yang artinya LKPD berbasis Scientific Approach pada materi pecahan perlu revisi kecil dan tidak perlu dilakukan validasi kembali.

Revisi tersebut berdasarkan saran dan masukan ahli tersebut dapat dilihat Tabel 5. Saran Perbaikan Validasi Ahli Materi

\begin{tabular}{|c|c|c|c|}
\hline No & Aspek & $\begin{array}{l}\text { Saran/ masukan untuk } \\
\text { perbaikan }\end{array}$ & Hasil Perbaikan \\
\hline 1 & Kualitas Isi & $\begin{array}{l}\text { Materi samakan dengan } \\
\text { indikator pada konsep } \\
\text { pecahan } \\
\text { - Contoh soal perlu ditambah }\end{array}$ & $\begin{array}{l}\text { - Materi dalam LKPD sudah } \\
\text { sama pada indikator konsep } \\
\text { pecahan } \\
\text { - Contoh soal dalam LKPD } \\
\text { sudah ditambah }\end{array}$ \\
\hline 2 & Kooperatif & $\begin{array}{l}\text { Menumbuhkan keinginan } \\
\text { peserta didik untuk tanya } \\
\text { jawab dengan guru maupun } \\
\text { temannya, bahasa dirubah } \\
\text { agar lebih komunikatif. }\end{array}$ & $\begin{array}{l}\text { - Bahasa yang digunakan } \\
\text { sudah di ubah menjadi lebih } \\
\text { komunikatif }\end{array}$ \\
\hline 3 & Bahasa & $\begin{array}{l}\text { - Penulisan perlu di cek dan } \\
\text { di perbaiki kembali }\end{array}$ & 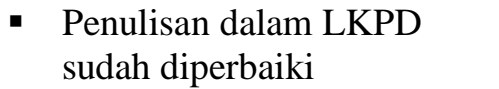 \\
\hline 4 & Motivasi & $\begin{array}{l}\text { Motivasi untuk } \\
\text { mengerjakan soal-soal } \\
\text { diperjelas lagi }\end{array}$ & $\begin{array}{l}\text { - Motivasi untuk } \\
\text { mengerjakan soal diperjelas } \\
\text { sudah diperjelas }\end{array}$ \\
\hline 5 & $\begin{array}{l}\text { Ilustrasi } \\
\text { (Gambar, } \\
\text { Tabel, Peta } \\
\text { Konsep) }\end{array}$ & $\begin{array}{l}\text { - Ilustrasi perlu di cek dan } \\
\text { diperbaiki lagi }\end{array}$ & $\begin{array}{l}\text { - Ilustrasi dalam LKPD sudah } \\
\text { dierbaiki }\end{array}$ \\
\hline 6 & Evaluasi & $\begin{array}{l}\text { - Soal-soal pada alat evaluasi } \\
\text { perlu ditambah }\end{array}$ & $\begin{array}{l}\text { - Soal-soal pada alat evaluasi } \\
\text { sudah ditambah }\end{array}$ \\
\hline
\end{tabular}

Adapun saran perbaikan oleh ahli media dapat dilihat pada Tabel 6 sebagai berikut:

Tabel 6

Saran Perbaikan Validasi Ahli Media

\begin{tabular}{cccc}
\hline No & Aspek & \multicolumn{2}{c}{$\begin{array}{l}\text { Saran/masukan untuk } \\
\text { perbaikan }\end{array}$} \\
1 & $\begin{array}{l}\text { Daya } \\
\text { Tarik }\end{array}$ & $\begin{array}{l}\text { - Warna sampul gunakan } \\
\text { warna biru muda atau yang } \\
\text { lebih cerah }\end{array}$ & $\begin{array}{l}\text { Hasil Perbaikan } \\
\text { dengan warna biru muda agar } \\
\text { lebih cerah }\end{array}$ \\
2 & $\begin{array}{l}\text { Ukuran } \\
\text { Huruf }\end{array}$ & $\begin{array}{l}\text { Warna huruf pada daftar isi } \\
\text { sebaiknya jangan terlalu } \\
\text { banyak }\end{array}$ & $\begin{array}{l}\text { Warna huruf sudah diganti } \\
\text { dengan satu warna yaitu black } \\
\text { color }\end{array}$ \\
\hline
\end{tabular}


KOMARUDIN \&

PRISMA TEJA PERMANA

Adapun saran perbaikan validasi praktisi dapat dilihat pada Tabel 7 sebagai berikut: Tabel 7

Saran Perbaikan Validasi Praktisi

\begin{tabular}{|c|c|c|c|}
\hline No & Aspek & Saran/masukan untuk & Hasil Perbaikan \\
\hline 1 & Isi & $\begin{array}{l}\text { - Peta konsep kurang sesuai } \\
\text { dengan konten LKPD } \\
\text { - Pada soal disesuaikan } \\
\text { dengan peserta didik SD }\end{array}$ & $\begin{array}{l}\text { - Peta konsep telah } \\
\text { disesuaikan dengan konten } \\
\text { LKPD } \\
\text { - Gambar telah disesuaikan }\end{array}$ \\
\hline 2 & $\begin{array}{l}\text { Penampilan } \\
\text { fisik }\end{array}$ & $\begin{array}{l}\text { - Sampul cover kurang } \\
\text { cerah dan penampilan } \\
\text { terlalu ramai }\end{array}$ & $\begin{array}{llr}\text { - } & \text { Sampul cover } & \text { dan } \\
\text { penampilan } & \text { LKPD } & \text { sudah } \\
\text { diperbaiki } & & \end{array}$ \\
\hline
\end{tabular}

Setelah produk melalui tahap validasi oleh ahli materi, ahli media, ahli praktisi serta telah selesai diperbaiki, selanjutnya produk diuji cobakan terhadap 10 peserta didik.Adapun hasil uji coba LKPD dimaksudkan untuk menguji kemenarikan produk, yaitu dengan memberikan angket respon untuk menilai kemenarikan LKPD. Hasil respon peserta didik terhadap LKPD matematika berbasis Scientific Approach dapat dilihat pada Tabel 8 berikut ini:

\section{Tabel 8}

Hasil Uji Respon Peserta didik terhadap LKPD

\begin{tabular}{clc}
\hline No & Aspek & Jumlah Persentase \\
1 & Isi & $85,8 \%$ \\
2 & Bahasa & $80 \%$ \\
3 & Kooperatif & $84 \%$ \\
4 & Motivasi & $85 \%$ \\
5 & Penggunaan & $86 \%$ \\
6 & Ilustrasi & Evaluasi \\
7 & Penampilan & $82 \%$ \\
Persentase Rataan & $91 \%$ \\
Kriteria Interpretasi & Sangat Tinggi \\
\hline
\end{tabular}

Tabel 8 merupakan hasil uji Respon Peserta didik terhadap LKPD, produk yang telah dikembangkan mencapai persentase rataan $84,83 \%$ dengan kriteria interpretasi yang di capai yaitu sangat tinggi, hal ini berarti LKPD yang dikembangkan oleh peneliti mempunyai kemenarikan sangat tinggi untuk digunakan sebagai alat bantu dalam kegiatan pembelajaran pada materi pecahan untuk kelas V SD. Selain itu, tabel tersebut juga menunjukan bahwa LKPD yang dikembangkan pada aspek isi mencapai persentase $85.8 \%$, aspek bahasa mencapai persentase $80 \%$, pada aspek kekooperatifan mencapai persentase $84 \%$, aspek motivasi $85 \%$ dan $86 \%$ di capai pada aspek penggunaan ilustrasi, sedangkan pada aspek evaluasi dan penampilan fisik yaitu berjumlah $82 \%$ dan $91 \%$, dari keseluruhan jumlah persentase tersebut mencapai kriteria sangat tinggi. Sehingga, dapat disimpulkan bahwa LKPD yang dikembangkan sangat menarik sebagai bahan pembelajaran.

Secara garis besar hasil uji respon peserta didik terhadap LKPD dapat dilihat pada Grafik pada Gambar 4 sebagai berikut:

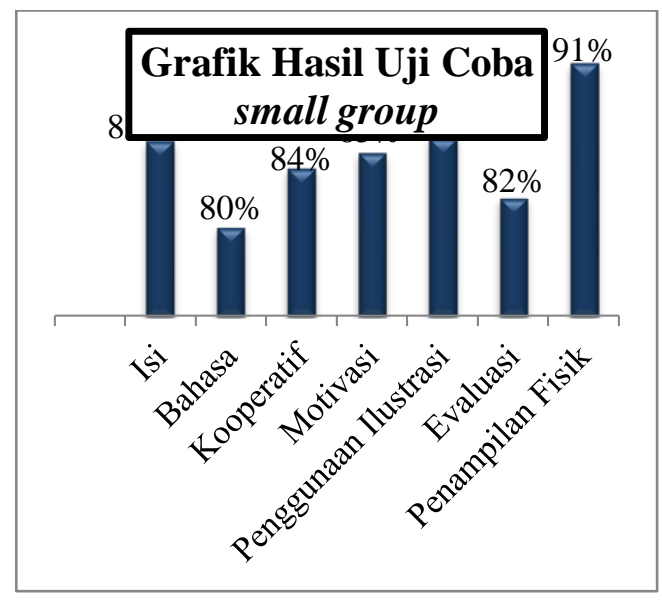

Gambar 4. asil Uji Coba Small Group 
Pada langkah smallgroup, 32 peserta didik. Uji inidimaksudkan untuk meyakinkan data dan mengetahui kemenarikan produk secara luas.Peserta didik dalam smallgroup ini diberi angket untuk menilai kemenarikan LKPD. Tahapini dilaksanakan diSDN 1 Way Dadi.Hasil smallgroup dapat dilihat pada Tabel 9 berikut ini.

Tabel 9.

Hasil SmallGroup Peserta didik

\begin{tabular}{llc}
\hline $\mathrm{N}$ & \multicolumn{1}{c}{ Aspek } & Jumlah \\
$\mathrm{o}$ & \multicolumn{1}{c}{ Persentase } \\
1 & Isi & $88,4 \%$ \\
2 & Bahasa & $88 \%$ \\
3 & Kooperatif & $83,5 \%$ \\
4 & Motivasi & $90,3 \%$ \\
5 & Penggunaan & $87,3 \%$ \\
& Ilustrasi & $89,6 \%$ \\
6 & Evaluasi & $90,6 \%$ \\
7 & Penampilan & Fisik \\
Jumlah & $617,7 \%$ \\
Persentase rataan & $88,24 \%$ \\
Kriteria Interpretasi & Sangat Tinggi \\
\hline
\end{tabular}

Berdasarkan hasil yang didapat dari smallgroup dari setiap aspek angket berupa isi LKPD memperoleh jumlah persentase $88,4 \%$, bahasa yang digunakan dalam LKPD diperoleh penilaian dengan jumlah $88 \%$, dan 83,5\% di capai pada aspek kooperatif, motivasi dalam LKPD memperoleh jumlah nilai $90,3 \%$, penggunaan ilustrasi mencapai 87,3, evaluasi mencapai 89,6 dan penampilan fisik yaitu 90,6\%. Dari keseluruhan penilaian setiap aspek diperoleh jumlah persentase yaitu 617,7\%, dengan persentase $88,24 \%$ dengan kriteria interpretasi kemenarikan sangat tinggi, sehingga tidak dilakukan perbaikan produk LKPD yang dikembangkan.

Secara garis besar hasil smallgroup dapat dilihat pada Grafik pada Gambar 5 sebagai berikut.

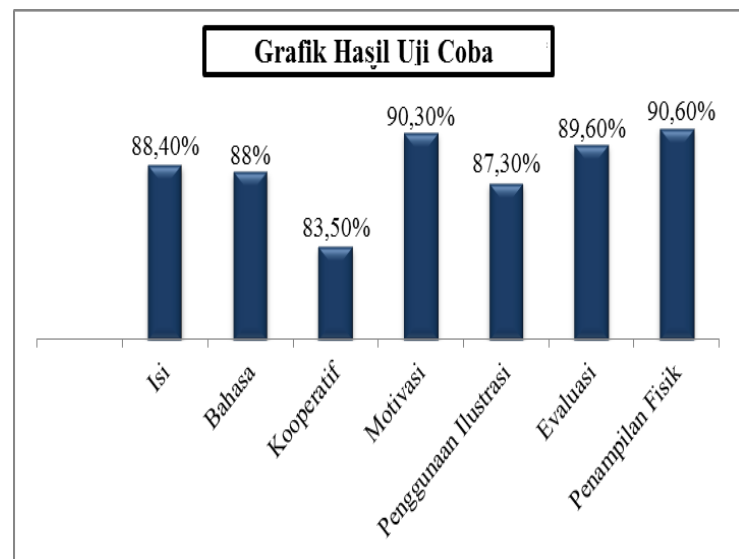

Gambar 5. Grafik Hasil Uji Expert Review dan One-to-one Evaluation

2. Pembahasan

Penelitian dan pengembangan didefinisikan sebagai studi sistematis terhadap pengetahuan ilmiah yang lengkap atau pemahaman tentang subjek yang diteliti. Penelitian ini diklasifikasikan sebagai dasar atau terapan sesuai dengan tujuan peneliti yaitu untuk mengembangkan LKPD berbasis Scientific Approach pada materi pecahan. Untuk menghasilkan produk LKPD yang dikembangkan, maka peneliti menggunakan prosedur penelitian dan pengembangan yang digunakan adalah dengan model penelitian pengembangan Sugiyono (2011: 11) yang diadaptasi dari BorgandGallyang terdiri atas empat langkah penelitian dan pengembangan, yaitu: 1) Self Evaluation; 2) Expert Reviewdan One-to-one evaluation; 3) SmallGroup (kelompok kecil); dan 4) Field Test (Uji lapangan).

Hasil validasi dilakukan oleh ahli materi dan ahli media serta praktisi yaitu guru matematika SD. Hasil penilaian pada ahli materi mencapai kriteria interpretasi Tinggi yaitu dengan persentase rataan mencapai $70 \%$. Persentase rataan yang dicapai oleh ahli media yaitu $80 \%$ dengan kriteria Sangat Tinggi. Validasi juga dilakukan oleh praktisi yaitu guru 
matematika SD, berdasarkan hasil rekapitulasi nilai bahwa persentase rataan pada validasi praktisi mencapai 79\% dengan kriteria interpretasi Tinggi.

Penelitian yang dilakukan diuji cobakan melalui dua tahap yaitu uji kelompok kecil dan kelompok besar.Hasil rataan kemenarikan yang diperoleh yaitu $85,30 \%$ untuk uji coba kelompok kecil dan 87,86\% untuk uji coba kelompok besar, ini berarti LKPD berbasis Scientific Approach yang dikembangkan dalam kriteria interpretasi kemenarikan yang sangat tinggi sebagai sumber belajar.

\section{a. Kelebihan Produk Hasil Pengembangan}

Produk hasil pengembangan ini memiliki beberapa kelebihan sebagai berikut ini :

1) LKPD berbasis Scientific Approachpada materi pecahan ini memberikan pengetahuan baru bagi peserta didik.

2) LKPD berbasis Scientific Approachpada materi pecahan dapat memotivasi peserta didik untuk lebih semangat dalam belajar karena memuat kata-kata motivasi.

3) LKPD berbasis Scientific Approach yang dikembangkan mendorong peserta didik untuk belajar secara mandiri dan lebih menarik karena peserta didik dituntut untuk lebih aktif dalam kegiatan pembelajaran.

4) LKPD yang dikembangkan disajikan sesuai dengan Scientific Approach yang menjadikan peserta didik lebih aktif yaitu dengan metode diskusi serta terdapat predikat penghargaan kelompok menambah semangat untuk belajar peserta didik.

5) Penampilan fisik LKPD berbasis Scientific Approach yang dikembangkan memiliki perpaduan warna yang menarik, serta dilengkapi dengan emoticon yang lucu sesuai dengan perkembangan anak SD.

b. Kekurangan Produk Hasil Pengembangan

Produk pengembangan penelitian ini memiliki beberapa kelemahan sebagai berikut ini :

1) LKPD yang dikembangkan hanya menggunakan Scientific Approachmateri pecahan.

2) LKPD berbasis Scientific Approach yang dikembangkan hanya dibatasi pada KD operasi hitung pecahan dan aplikasinya dalam kehidupan sehari-hari.

\section{SIMPULAN DAN SARAN}

Berdasarkan hasil penelitian, hasil penilaian pada ahli materi mencapai kriteria interpretasi Tinggi, dengan persentase rata-rata mencapai $70 \%$ dan ahli media yaitu $80 \%$ dengan kriteria Sangat Tinggi. Validasi juga dilakukan oleh ahli praktisi yaitu guru matematika SD, berdasarkan hasil rekapitulasi nilai bahwa persentase rata-rata pada validasi praktisi mencapai $79 \%$ dengan kriteria interpretasi Tinggi. Respon kemenarikan peserta didik SD kelas $\mathrm{V}$ terhadap LKPD berbasis scientific approach pada materi pecahan yang dikembangkan oleh peneliti baik dalam uji coba kelompok kecil yaitu 10 peserta didik maupun uji coba kelompok besar dengan melibatkan 32 peserta didik termasuk dalam kategori Sangat Tinggi. Hal ini menunjukkan bahwa LKPD yang dikembangkan memenuhi kriteria kelayakan dan kemenarikan bagi peserta didik dan dapat digunakan sebagai salah satu media penunjang dalam pembelajaran matematika. 
Adapun saran untuk penelitian selanjutnya yaitu agar dapat mengembangkan bahan ajar LKPD, maupun bahan ajar lain seperti buku, modul, RPP dan lain lain guna memaksimalkan proses pembelajaran agar tercapainya tujuan yang diinginkan, ataupun peneliti selanjutnya dapat mengembangkan LKPD dengan menggunakan pendekatan pendekatan pembelajaran lain.

\section{E. DAFTAR PUSTAKA}

Agoestanto, Arief, \& Safitri, S. N. (2013). Keefektifan Pembelajaran Matematika Mengacu Pada Missouri Mathematics Project Terhadap Kemampuan Pemecahan Masalah. Prosiding Seminar Nasional Matematika VII UNNES, 71-77.

Alba, F. M., Khotim, M., \& Junaedi, I. (2013). Keefektifan Model Pembelajaran Generatif dan MMP Terhadap Kemmpuan Pemecahan Masalah. Kreano: Jurnal Matematika KreatifInovatif, 4(2), 131-137.

E, S., S, M., \& Mashuri. (2015). Studi Perbedaan Keefektifan Pembelajaran LC-5E dan CIRC Terhadap Kemampuan Pemecahan Masalah Matematika. Jurnal Matematika Kreatif Inovatif, 6(1), 26-32.

Febriana, L. C., Sulur, \& Yudyanto. (2014). Pengembangan Lembar Kerja Siswa (LKS) Fisika Materi Tekanan Mencakup Ranah Kognitif, Afektif dan Psikomotor Sesuai Kurikulum 2013 untuk Siswa SMP/MTs. Jurnal Universitas Negeri Malang, 2(1), 1-12.

Fitriana, D., Yusuf, M., \& Susanti, E. (2016). Pengembangan Lembar Kerja Siswa Menggunakan
Pendekatan Saintifik Untuk Melihat Berpikir Kritis Siswa Materi Perbandingan. Jurnal Pendidikan Matematika, 10(2), 1-17.

Imamah, F. U., \& Toheri. (2014). Pengaruh Penggunaan Kombinasi Metode Pembelajaran Discovery Learning Dan Brain Storming Terhadap Kemampuan Pemecahan Masalah Pada Pokok Bahasan Himpunan. EduMa, 3(1), 120-137.

Kurniasari, I., Dwijanto, \& Soedjoko, E. (2014). Keefektifan Model Pembelajaran MMP Dengan Langkah Pemecahan Masalah Polya Terhadap Kemampuan Berpikir Kreatif Siswa. Unnes Journal of Mathematics Education, 3(2), 1-6.

Lipianto, D., Budiarto, M. T., Matematika, J., Surabaya, U. N., Matematika, J., \& Surabaya, U. N. (2013). Analisis kesalahan siswa dalam menyelesakan soal yang berhubungan dengan persegi dan persegipanjang berdasarkan taksonomi solo plus pada kelas vii. Mathedunesa, 2(1).

Minarni, A. (2012). Pengaruh Pembelajaran Berbasis Masalah Terhadap Kemampuan Pemecahan Masalah Matematis. In Prosiding.

Pratama, H., \& Prastyaningrum, I. (2016). Pengaruh Model Pembelajaran Project Based Learning Berbantuan Media Pembelajaran Pembangkit Listrik Tenaga Mikrohidro Terhadap Kemampuan Berpikir Kritis. Jurnal Penelitian Fisika Dan Aplikasinya (JPFA), 6(2), 44-50.

Purwanto, A. (2014). Implementasi Model Learning Cycle 5E Disertai LKS Untuk 
Meningkatkan Aktivitas, Keterampilan Proses Sains dan Hasil Belajar Biologi. Jurnal Pendidikan Biologi, 5(1), 1-11.

Sugiyono. (2011). Metode Penelitian Kuantitatif Kualitatif dan $R \& D$. Bandung: Alfabeta.

Supardi, N., Rakhmawati, R., \& Rinaldi, A. (2018). Lembar Kerja Peserta Didik Berbasis Kegiatan Transaksi Kewirausahaan Materi Sistem Persamaan Linier Dua Variabel. Desimal: Jurnal Matematika, 1(1), 49-55.

Susialita, T. (2016). The Development Of Audio-Visual Student Portofolio(LKS) Contextual Teaching And Learning-Based (CTL) On Sound Chapter Of Science Suject For Deaf Student. Jurnal Pendidikan IPA Indonesia, 5(2), 192-198.

https://doi.org/10.15294/jpii.v5i2 .6734

Syazali, M. (2015). Pengaruh Model Pembelajaran Creative Problem Solving Berbantuan Maple II Terhadap Kemampuan Pemecahan Masalah Matematis. Al-Jabar, 6(1), 91-98.
Utami, B., Hastuti, B., Yatimah, S., Padmini, S., \& Arroyan, F. (2013). Penerapan Siklus Belajar 5E Disertai LKS Untuk Peningkatan Kualitas Proses dan Hasil Belajar Kimia. Cakrawala Pendidikan, 32(2), 315-325.

Yuliati, L., Riantoni, C., \& Mufti, N. (2018). Problem Solving Skills on Direct Current Electricity through Inquiry-Based Learning with PhET Simulations. International Journal of Instruction, 11(4), 123-138. 